\title{
Religious feeling and authenticity: Dialogues between William James and Bernard Lonergan
}

\author{
Toan Dang Ngo - Nikolay A. Mashkin - Valeria L. Zakharova - Olga V. \\ Popova - Larisa Lutskovskaia
}

DOI: 10.18355/XL.2021.14.03.07

\begin{abstract}
The paper analyzes the tricky phenomenon of religious feelings related to the question of authenticity. The challenge to describe and make sense of this elusive relationship, providing one exists at all, becomes clearer against the background of two important figures dealing with the psychology of religion - William James (primarily a psychologist) and Bernard Lonergan (primarily a theologian). While James was a naturalist psychologist who put his study on a background of human nature and followed academic scientific discipline, Lonergan was a Christian theologian who set the goal for his whole system not on the level of cognition but on the transcending dimension of being-in-love with God. They both avoided the extremes of their positions and reached out to a more balanced way of understanding religion in its complexity and sometimes ambiguous significance in the lives of human moral subjects.
\end{abstract}

Key words: William James, Bernard Lonergan, religious feeling, authenticity, psychology of religion

\section{Introduction}

When Friedrich Schleiermacher (1768-1834) made his call for a shift of attention from the doctrinal and institutional aspects of religion to innermost human emotions (Schleiermacher, 1958: 18), he did not only counter the scientists and rationalists of his time but also opened an invitation to further discussion about religious feeling and human person which are clearly the interest of psychology. Since that moment, religious experience and feeling have become a center and still an unsettled debate in the field of Religious Studies (Arazi, Birnbacher, 2004: 902). Among many scholars of religion who had paid great attention to that discussion and tried to look for possible connections and complements between psychology and religion, William James (1842-1910) and Bernard Lonergan (1904-1984) are two remarkable cases. Lonergan, as the later scholar, clearly referred to Sigmund Freud and Carl Gustav Jung in his writings. Yet, it seems that the name of William James - another giant in the field of psychology of religion-had never been mentioned (Kim, 2010: 983). Despite that, James's and Lonergan's understandings of religious feeling and religion, in general, have many common points.

In fact, James and Lonergan came at religious feeling and human authenticity from two opposite directions: James was a naturalist psychologist who put his study on a background of human nature and follows academic scientific discipline; and Lonergan was a Christian theologian who set the goal for his whole system clearly not on the level of understanding but on the transcending dimension of being-in-love with God. (Kompatseva, 2020) Yet, they both avoided the extreme of their positions and reached out to a more balanced way of understanding religion. As a follower of academic disciplines, James tried to overcome the dualism of empiricism and idealism and connect empirical science to irrational dimension by emphasizing the deepest aspect of human experience and feeling at the boundary with the unconscious (James, 1977: xix-xxi). As a theologian of the Church, Lonergan tried to connect God's love with the dimension of reason by specifically attending on intentionality and adding it into

XLinguae, Volume 14 Issue 3, June 2021, ISSN 1337-8384, eISSN 2453-711X 
the human transcendental process toward the dimensions of ethics and religion (Kanaris, 2002: 2). As they reach out to the opposite to rebalance their approaches, James and Lonergan came close to each other at the middle and started a dialogue through distant times. They are typical examples of how psychology and religion can meet each other with the right minds and right attitudes.

\section{The Dialogue on Religious Feelings}

Concerning religious feeling, both James and Lonergan set on an empirical approach where human experience is the start of all inquiries. The Varieties of Religious Experiences (1902) of James is a study of human nature, and Method in Theology (1972) of Lonergan is an investigation within man's horizon. What is most important for them is human experience in its deepest level, which is immediate, dynamic, and empirical. Religious experience for James is the "first-hand individual experience" (James, 1978: 306) that comes to us in the immediacy of our consciousness with a wider self or environment that is outside our ordinary rational perception (James, 1978: 135, 461). For Lonergan, religious experience is given to us internally as God's grace that we can only be aware of its occurrence but unable to sense or know it (Lonergan, 1990: 106-107). Rather than investigating further the source of religious experience, both James and Lonergan seem to be content with an unknown environment continuous with human consciousness, which is pretty much the same thing as unconsciousness, and start off their study of religious phenomenon from what follow the occurrences of mystical experience in the "cognitive aspect" (James's words) (James, 1978: 369) or in "man's horizon" (Lonergan's words) (Lonegan, 1990: 103). The two agree that religious experience spontaneously manifests in feelings, and these feelings are also various. The power of feeling is that it carries the value and meaning of religion and can strongly affect human "total reaction upon life" (terms of James) (James, 1978: 40). Without feeling, reason on its own cannot give one's self true authenticity (terms of Lonergan). Humans cannot experience transcendence as long as they ignore their feelings. Without paying attention to feelings, there will be no theory or philosophy for religion (Lonergan, 1985: 122-125).

Both James and Lonergan agreed that religious feeling is not merely a matter of bodily sensibility. In "What is Emotion?" (1884) James distinguishes two types of emotion: standard emotion and the other, which could be labeled the non-standard. The standard emotions, for James, are those with obvious bodily "expressions" such as hunger, cold, hot, etc., and without these bodily phenomena, they are nothing but ideas of feeling (James, 1884: 189). It is obvious that religious feelings should not be included in this category since they do not necessarily have these bodily reactions accompanied (for example, the fear of God does not need to be caused by nor accompanied by shaken legs). The connection that we should pay attention to here is not to the body but to other inner processes - experience and reasoning. Religious feeling is an inner and personal matter.

In Method, Lonergan argued a similar issue but elevated it in a different way. He differentiated the non-intentional emotions from the intentional and meaningful feelings borrowing the idea of Dietrich von Hildebrand:

"On this topic I would . . . distinguish non-intentional states and trends from intentional responses. The former may be illustrated by such states as fatigue, irritability, bad humor, anxiety, and the later by such trends or urges as hunger, thirst, sexual discomfort. The states have causes. The trends have goals. But the relation of the feeling to the cause or goal is simply that of effect to cause, of trend to goal. The feeling itself does not presuppose and arise out of perceiving, imagining, representing the cause or goal ... Intentional response, on the other hand, answer to what is intended, apprehended, represented. The feeling relates us, not just to a cause or an end, but to an object. Such feeling gives intentional 
consciousness its mass, momentum, drive, power. Without those feelings our knowing and deciding would be paper thin. Because of our feelings ... we are oriented massively and dynamically in a world mediated by meaning." (Lonergan, 1990: 30-31)

There is a clear distinction between non-intentional states and trends and intentional responses. Lonergan calls only the later feeling. The difference between these two is that the first kind has no relation to any object, while for the second object is a must. By "object," Lonergan means intentionality: it does not just appear to our consciousness, but we are also aware of it. Non-intentional emotions come to our senses, and we immediately find their 'meanings' in their causes or goals (e.g., being fatigue means too much work, or being hunger means we need food). They are similar to James' standard emotions but also include some non-bodily states and trends (anxiety, irritability). Intentional feelings are different; they need objects and connect us to them in a way that the more we observe and reflect upon them, the more feelings with meanings we have (e.g. we 'pour' our feelings into something; we feel/love/hunger for something/someone; the more we think about our recent broken love, the more painful and meaningful it becomes). That is the most important criterion to distinguish the two kinds. Compared to intentional feelings, nonintentional emotions are paper-thin because they simply bring us the information of their causes or goals without much meaning. We respond to non-intentional emotions with non-intentional behaviors (e.g., we immediately withdraw our hand without intention when we touch something hot); we respond to intentional feelings with our consciousness intentionality and meanings (e.g., contemplation of love or the numinous). Only feelings with meanings are affective to our knowing and deciding. In this sense, the mysterium tremendum fascinans is not religious because it was given mysteriously, amazingly, or lovely. It is religious because the subject who receives it can and do continuously reflect upon it, enrich it, and find more and more meanings, eventually the ultimate meanings, in it. Therefore, feelings as intentional responses interrelate closely with levels of consciousness intentionality (experience, understand, judgment, decision) and come into focus in Lonergan's works.

James saw that religious feelings are not simply fixed in one single type but vary in forms and meanings depending on how we reflect upon them. He strongly criticized the idea of a sui generis religious feeling:

"As concrete states of mind, made up of a feeling plus a specific sort of object, religious emotions, of course, are psychic entities distinguishable from other concrete emotions; but there is no ground for assuming a simple abstract 'religious emotion' to exist as a distinct elementary mental affection by itself, present in every religious experience without exception. As there thus seems to be no one elementary religious emotion, but only a common storehouse of emotions upon which religious objects may draw, so there might conceivably also prove to be no one specific and essential kind of religious object, and no one specific and essential kind of religious act." (James, 1978: 34-35)

As intentional responses, religious feelings for Lonergan is also collective. He described religious feelings as a series of positive feelings: "it is a conscious dynamic state of love, joy, peace, that manifests itself in acts of kindness, goodness, fidelity, gentleness, and self-control" (Lonergan, 1990: 106). Even though Lonergan names religious feeling 'the feeling of falling in love with God,' similar to James, he means a collection of emotions rather than one special and pure religious feeling.

For Lonergan, how the ultimate question affects individual life is only comparable to the experience of falling in love. The affections may vary, but they all point toward human authenticity. If we have to make a distinction between the sacred and the profane, if we have to suspect and justify our tradition, if we have to confront the evils

XLinguae, Volume 14 Issue 3, June 2021, ISSN 1337-8384, eISSN 2453-711X 
within us, then they are only authentic as long as we do that for the purpose of selftranscendence (Lonergan, 1985: 120). Religious experience is the "experience of fulfillment, of complete integration, of a self-actualization that is the unbounded source of good will and good deeds" (Lonergan, 1985: 133). Therefore, unlike William James, who distinguishes two general types of religious feeling (the healthymindedness and the sick-soul) (James, 1978: 121), for Lonergan "[f]eeling of guilt, a sense of one's uncleanness, denunciations of unfaithfulness, all express failures to be authentic" (Lonergan, 1990: 123). He emphasizes only the positive effects of religious experience because religious experience for him is the experience of being-in-love. The power of religion is the self-transcendence of being-in-love. The question of religious feeling, therefore, is connected to the question of self-transcendence and authenticity.

\section{The Dialogue on Self-Transcendence and Authenticity}

The study of religion, for James, should leave the outer surface to find its real subject in such inner and personal processes of religious experience and feeling (James, 1978: 14). Being religious for James is to establish ourselves in possession of ultimate reality at the only point at which reality is given us to protect (James, 1978: 448-449). To live at that moment then is to be religious. But this process, to James, is "essentially private and individualistic," out of our rational formulation, and can only be achieved with the power of feeling (James, 1978: 421). Therefore, he strongly criticized proponents of rational transcendentalism that they could not transform beyond the individual experience, and they could not do religion without personal religious feeling (James, 1978: 443-444). According to James, if there is some kind of transcendental process, it must be that of the emotional self as a struggle inward. Religious feelings are important to human self-transcendence. James believes that feeling is the key to human diversity and unique individuality. He did not use the term "authenticity" but "human authority and illumination" (James, 1978: 25). What makes each of us a unique being is not our conception but the susceptibility of emotional excitement and different desires and repressions (James, 1978: 239). The dimension of religious feeling has transcendental power to move us beyond our normal capacity to a human being. The values and meanings of religion, therefore, are carried through their affections in religious feeling. Religious feeling is "an absolute addition to the Subject's range of life," "a new sphere of power," and an "added dimension of emotion... where morality strictly so called can at best but bow its head and acquiesce" (James, 1978: 51). In this sense, the religious feeling is an important element, if not the whole, of something More - the key for self-transcendence that James expected to convince both religious believers and scientists (Taves, 2009: 12).

Religious feeling, then, can affect our way of life - the way we create our meaning and happiness and transcend ourselves to higher goods. Being faithful to our feelings is of utmost importance to human self-transcendence and authority. To transcend from wishing to willing, to move up from boring ideas to creativeness, to carry out an idea to action, to convert to a religious belief, all require a decisive push of the corresponding feeling. "The difference between willing and merely wishing, between having ideals that are creative and ideals that are but pinings and regrets, thus depends solely either on the amount of steam-pressure chronically driving the character in the ideal direction, or on the amount of ideal excitement transiently acquired." (James, 1978: 244)

We may have many ideas, but without the push of feeling, all are just dreams. It is feeling that makes them counted in our personality or actions. Ideas make up the content of our actions, but the feeling is what decides the actor's true authority, which, in this case, Lonergan would call the "authenticity" of the self in actions. Even when your actions are poor, it is still better than being hypocritical because 'it is the feeling that is counted' as people always say in such cases. 
Similar arguments were posed by Lonergan. From his perspective, those who want to transcend themselves cannot ignore feelings and depend solely on intellectual knowledge. Rejecting this fact would bring forth the conflict between the limitation and transcendence between the self that transcended and the self that has not transcended, rather than bridging them to create a lively circulation of evolution. Religious feelings have the power to motivate, even to some extent, to take over the subject into the recognition of true values and action (Lonergan, 1990: 123). Lonergan believed that this dynamic state of being-in-love belongs to the fourth level of conscious intentionality. It is not simply about experiencing religious feelings as something given, nor about understanding them. It is about assessing their true value as human consciousness perceives them on the fourth level, the level of free deliberation:

"It is conscious on the fourth level of intentional consciousness. It is not the consciousness that accompanies acts of seeing, hearing, smelling, tasting, touching. It is not the consciousness that accompanies acts of inquiry, insight, formulating, speaking. It is not the consciousness that accompanies acts of reflecting, marshalling and weighing the evidence, making judgments of fact or possibility. It is the type of consciousness that deliberates, makes judgments of value, decides, acts responsibly and freely ... the gift of God's love occupies the ground and root of the fourth and highest level of man's intentional consciousness. It takes over the peak of the soul, the apex animae." (Lonergan, 1990: 106-107)

There are four stages of authenticity correlated to Lonergan's four realms of meaning: common sense, theory, interiority, and transcendence. The problem of traditional theology and religious studies, according to Lonergan, is that religious expression is confined in the realm of common sense or the realm of theory only. Controversies are unavoidable because the older theology does not distinguish the realm of interiority. Therefore, as it moves upward in its explanation of religion, it will end up in mysticism if it sets the inner experience within the context of common sense or in metaphysics if the context is the realm of theory (Lonergan, 1990: 120). The only way to overcome these conflicts is to overcome the dualism of commonsense and theory, reasoning and feeling, in other words, to unite the common sense and theory in the realm of interiority (Lonergan, 1990: 114-115). Authenticity can only be achieved by setting our feet in the realm of interiority, beyond the dualism of empiricists and rationalists. The moment of religious authenticity is when we move beyond the separation between the ideal and the actual, the conflict between our feeling and reasoning to deliberately make decisions and take actions that are felt great to us both emotionally and rationally. Lonergan's argument until this point is very similar to what we have seen previously with James. However, while James does not develop this aspect much in The Varieties, interiority and authenticity are key concepts in Lonergan's works.

"Man achieves authenticity in self-transcendence" (Lonergan, 1990: 104), according to Lonergan. Hence the process of self-transcendence is also the struggle against unauthenticity within the human self. Authenticity means to be true to the origin. Authenticity in our common sense or our experiential level is to be conscious, to be attentive, and then to know the deepest source of our experience and feeling. Sensitivity is the origin of many experiences, but the human experience is much more than that. This search for and question about the authentic human experience goes far beyond sensitivity and, in essence, is unrestricted (Lonergan, 1990: 104). The authentic theory is an understanding originated from one's own experience, through one's own critical thinking, not simply or mechanically borrowed, influenced, or forced by others. An authentic interiority is achieved when rational judgments are based on one's own values, which are apprehended by one's own authentic feelings.

XLinguae, Volume 14 Issue 3, June 2021, ISSN 1337-8384, eISSN 2453-711X 
An authentic decision is made from both what one knows and how one feels, in a fully self-controlled act and free from any rational or emotional conflict. When the most important decisions that have the power to transcend one's being are deliberately made in that way, one can call them their religious moments (Lonergan, 1990: 120121). This explanation of authenticity may sound akin to a certain understanding of mystical intuition as moments of the complex and unconscious interaction of emotions, reason, and experience in some Western philosophical and religious tradition (Nguyen et al., 2020: 220), but Lonergan worked hard to bring it into consciousness, into man's horizon rather than leaving it unquestioned as intuition and revelation. One must go through a kind of "first-person practice," starting with oneself and the internal dynamic structure of knowing to first become personally authentic before reaching out to work with others' cognitive operations and actions and contribute to the community in an authentic manner (Coghlan, 2008: 363-364).

\section{Conclusion}

Both James (the psychologist) and Lonergan (the theologian) perceived feelings as a key operation of religious life and recognized the necessity of putting religious feeling in comparison and connection with other feelings and functions of the human mind. Religious experience and feeling were the focus of James' scrutiny. He approached the issue from a naturalist perspective. Lonergan, on the other hand, set the goal of his study in religious self-transcendence. The method of James was more phenomenological; that of Lonergan was more heuristic. These differences can be the reason why Lonergan does not pay attention to the works of James in his studies of feeling but instead refers to Max Scheler and Dietrich von Hildebrand. Scheler and von Hildebrand are the only ones talking about morality based on values (apprehended in feelings) which is the focus of Lonergan (Cronin, 2006: 238-239). Scheler was a fan of Christian love in his Ressentiment which exerts quite an influence among the Christian scholars, including von Hildebrand (a famous Christian theologian). In contrast, William James was a naturalist (Cronin, 2006: 233, 237). Therefore, it was quite natural for Lonergan, a theologian who criticized naturalism, to not refer to James's naturalistic and pragmatic ideas. Nevertheless, as we have shown, the consensus over religious feelings between James and Lonergan are enlightening in the exploration of ambiguous religious experience.

Another common theme that requires the collaboration of both psychology and religion is the construction of the personality. A complete, united self and a healthy personality that makes it possible for the development of humans as living beings (moral subjects), are common goals of these two human practices. The idea of religion as self-transcendence toward perfect authenticity is also agreed upon by both James and Lonergan. Lonergan's further developments in self-transcendence and authenticity (Helminiak et al., 2020) might be called by James 'philosophical and theological' for they are highly abstract. But the interrelationship between feeling and reasoning within the realm of the human interiority of Lonergan is something that can balance James' emphasis on feeling. Like James, Lonergan also takes an empirical stance and sees religious feeling as a complex phenomenon but pays more attention to the relations between religious feeling and human experience and reasoning. Authentic human personality cannot be found in the rejection of rational approach but in bringing both reason and feeling into their proper terms in the realm of interiority (Ormerod, 2005: 21). According to Matthew Pettilo (2010), this approach of Lonergan has moved beyond the dilemma of a universal experience core and the diverse particularity of religion (Pettilo, 2010: 952-957).

Looking back at the history of psychology, founders of modern psychology like S. Freud, C.G. Jung, and William James were all concerned with religion and presented their most important psychological theories in the context of religious affairs. However, later on, it seems that the relationship between these two practices has 
become one-sided in which theology has shown more interest in psychology than the other way around (Watts, 2010: 190). In our case of James and Lonergan, it was not by coincidence that they, independently and from opposite directions, were able to 'meet' each other on certain topics. The human inner world has always been a common ground and focus of both psychology and theology. Psychology should not be ignorant of faith as an important dimension of the self. And theology, as soon as it recognizes the key role of experience and feelings, cannot help but refer to findings in the field of psychology. With a profound concern for the human person and an open attitude to learning and studying, psychologists and theologians will eventually and certainly find each other somewhere in the middle of their distinct paths. The dialogue that is conducted during this meeting is a psychology of religious experience which is, as the Jesuit priest and psychoanalyst William W. Meissner admitted, "before all else a science of human behavior and experience" (Meissner, 1984: 6).

\section{Bibliographic references}

ARAZI, N.P. - BIRNBACHER, D. 2004. The Role of Cognition and Feeling in Religious Experience. In: Zygon, vol. 39, n. 4, pp. 901-917.

COGHLAN, D. 2008. Authenticity as first person practice: An exploration based on Bernard Lonergan. In: Action Research, vol. 6, n. 3, pp. 351-366.

CRONIN, B. 2006. Value Ethics: A Lonergan Perspective. Nairobi: Consolata Institute of Philosophy Press.

HELMINIAK, D.A. - FEINGOLD, B.D. - DONAHUE, M.J. 2020. Clarifications about Lonergan's "authenticity" for application in psychology. In: New Ideas in Psychology, vol. 57, n. 2, pp. 107-173.

JAMES, W. 1884. What is Emotion?. In: Mind, vol. 9, n. 34, pp. 188-205.

JAMES, W. 1978. The Varieties of Religious Experience: A Study in Human Nature. New York: Dolphin Books. (Original work published: 1902)

JAMES, W. 1977. Pluralistic Universe. Cambridge - Massachusetts - London: Havard University Press. (Original work published: 1907)

KANARIS, J. 2002. Bernard Lonergan's Philosophy of Religion: From Philosophy of God to Philosophy of Religious Studies. New York: State University of New York Press.

KIM, C-Y. 2010. William James and Bernard Lonergan on Religious Conversion. In: Heythrop Journal, vol. 51, n. 4, pp. 982-999.

KOMPANTSEVA, L. 2020. The Philosophy of Anthropocentrism in Organization of Social Networks: Extrapolation of Ideas of Bernard Lonergan (Canada) and The Ukrainian School of" Philosophy of Heart". In: Logos, vol. 103, n. 1, pp. 46-56.

LONERGAN, B. 1990. Method in Theology. Toronto: University of Toronto Press. (Original work published: 1972)

LONERGAN, B. 1985. A Third Collection: Papers by Bernard J.F. Lonergan. New York: Paulist Press.

MEISSNER, W.W. 1984. Psychoanalysis and Religious Experience. New Haven and London: Yale University Press.

NGUYEN, V. H. - SLIVKA, D. - TELEGINA, N.V. - ZAITSEVA, N.A. - SIZOVA, Z.M. 2020. Conception of intuition: From the Western philosophy, science, and religion to traditional Vietnamese philosophical thought. In: XLinguae, vol. 13, n. 3, pp. 216-227. DOI: 10.18355/XL.2020.13.03.18.

ORMEROD, N. 2005. Faith and Reason: Perspectives from McIntyre and Lonergan. In: Heythrop Journal, vol. 46, n. 1, pp. 11-22.

PETTILO, M. 2010. The Universalist Philosophy of Religious Experience and the Challenges of Post-Modernism. In: Heythrop Journal, vol. 51, n. 4, pp. 946-961.

XLinguae, Volume 14 Issue 3, June 2021, ISSN 1337-8384, eISSN 2453-711X 
SCHLEIERMACHER, F. 1958. On Religion: Speeches to Its Cultured Despisers. Translated by John Oman. New York: Harper \& Brothers. (Original work published: 1799)

TAVES, A. 2009. Bridging Science and Religion: "The More" and "The Less" in William James and Owen Flanagan. In: Zygon, vol. 44, n. 1, pp. 9-17.

WATTS, F. 2010. Psychology and theology. In Harrison, Peter (Ed.), The Cambridge Companion to Science and Religion. Cambridge: Cambridge University Press.

Words: 4486

Characters: 29179 (16,21 standard pages)

\section{Toan Dang Ngo}

Department of Philosophy

University of Social Sciences and Humanities

Vietnam National University, Hanoi

336 Nguyen Trai Street

Thanh Xuan District, Hanoi,

Vietnam

toannd@ussh.edu.vn

Prof. Nikolay A. Mashkin, Doctor

Plekhanov Russian University of Economics

36 Stremyannyi Pereulok

117997, Moscow

Russian Federation

mashkin.n.a@rea.ru

Assoc. Prof. Valeria L. Zakharova, $\mathrm{PhD}$

I.M. Sechenov First Moscow Medical University (Sechenov University)

8 Trubetskaya Street

119991, Moscow

Russian Federation

zkvaleria@mail.ru

Assoc. Prof. Olga V. Popova, PhD

Financial University under the Government of the Russian Federation

49 Leningradsky Prospect

125993, Moscow

Russian Federation

helga-popova@yandex.ru

Assoc. Prof. Larisa Lutskovskaia, $\mathrm{PhD}$

RUDN University - Peoples' Friendship University of Russia

6 Miklukho-Maklay st.,

117198, Moscow

Russian Federation

laravas@list.ru 